\title{
WEAITH, POVERTY
}

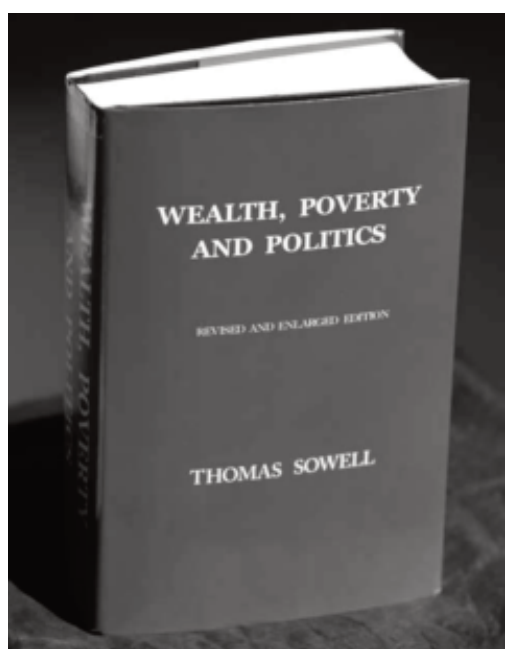

Wealth, Poverty and Politics is a new approach to understanding age-old issues about economic disparities among nations and within nations. These disparities are examined in the light of history, economics, geography, demography and culture.

Wealth, Poverty and Politics is also a challenge to much that is being said today about income distribution and wealth concentration- a challenge to the underlying assumptions and to the ambiguous words and misleading statistics in which those assumptions are embedded, often even by leading economists. This includes statistics about the much-discussed "top one percent."

This revised and enlarged edition should be especially valuable to those who teach, and who want to confront their students with more than one way of looking at issues that are too important to be settled by whatever the prevailing orthodoxy happens to be.

At a time when many politicians, academics and media commentators are focusing on income inequality, Thomas Sowell's Wealth, Poverty and Politics: An International Perspective offers a refreshing and stimulating view.

(Professor John B. Taylor, Stanford University)

A true gem in terms of exposing the demagoguery and sheer ignorance of politicians and intellectuals in their claims about wealth and poverty... Dr. Sowell's new book tosses a monkey wrench into most of the things said about income by politicians, intellectuals and assorted hustlers, plus it's a fun read.

(Professor Walter E. Williams, George Mason University)

Sowell... draws from this well of research to do what he has done so well for so long: question basic assumptions behind public policy and follow the facts where they lead him.

(Jason Riley, Wall Street Journal) 


\section{and POLITICS}

It's a scandal that economist Thomas Sowell has not been awarded the Nobel Prize. No one alive has turned out so many insightful, richly researched books. His latest is another triumph of crackling observations that underscore the ignorance of our economists and policymakers. His take on how culture, geography, politics and social factors affect how societies progress - or don't - will rile those addicted to political correctness but leave everyone else wiser. (Steve Forbes, Forbes magazine)

\section{O N T E N T S}

\begin{tabular}{|c|c|c|}
\hline \multicolumn{2}{|l|}{ Preface } & \multirow{2}{*}{$\begin{array}{l}\mathbf{v} \\
1\end{array}$} \\
\hline Chapter 1: & Issues & \\
\hline PART I: & GEOGRAPHIC FACTORS & 13 \\
\hline Chapter 2: & Waterways & 27 \\
\hline Chapter 3: & Lands & 43 \\
\hline Chapter 4: & Climate, Animals and Diseases & 61 \\
\hline PART II: & CULTURAL FACTORS & 85 \\
\hline Chapter 5: & Culture and Economics & 95 \\
\hline Chapter 6: & Cultural Diffusion & 118 \\
\hline Chapter 7: & Culture and Progress & 135 \\
\hline PART III: & SOCIAL FACTORS & 155 \\
\hline Chapter 8: & Population & 167 \\
\hline Chapter 9: & Mental Capabilities & 184 \\
\hline PART IV: & POLITICAL FACTORS & 215 \\
\hline Chapter 10: & Political Institutions & 225 \\
\hline Chapter 11: & Politics and Diversity & 249 \\
\hline Chapter 12: & The Welfare State & 273 \\
\hline PART V: & CONCLUSIONS & 307 \\
\hline Chapter 13: & Economic Differences & 319 \\
\hline Chapter 14: & Implications and Prospects & 352 \\
\hline Chapter 15: & Causation versus Blame & 382 \\
\hline Chapter 16: & Goals & 406 \\
\hline
\end{tabular}

Had such an approach been available in this reviewer's student days, his understanding of the world would be that much better.

(Library Journal) 